Egypt. J. of Appl. Sci., 36 (7-8) 2021

\title{
QUALITY AND PROPERTIES EVALUATION OF WHITE SOFT CHEESE MADE BY FREE OR IMMOBILIZED COAGULANT ENZYMES DURING STORAGE
}

Ahmed, M. A.

Dairy Technology Department, Animal Production Research Institute, Agriculture Research Center, Dokki, Giza, Egypt

\section{ABSTRACT}

The present study aimed to isolate calf rennet, bovine, and chicken pepsin enzymes from different sources, purified and immobilized on paraffin and honey waxes mixture $(1: 1, \mathrm{w} / \mathrm{w})$ to use in white soft cheese making as well as to compare it with the corresponding ones of free coagulant enzymes. The enzymes were extracted from the stomach of three different sources (big bovine stomach tissues, chicken gizzard and calf abomasum tissues). White soft Cheeses were made from standardized cow's milk (\%3.64 fat) using the former coagulants either free or immobilized. Cheese was stored at room temperature for 1, 30, 60, and 90 days.

Results indicated that cheese made using free enzymes had higher values of yield, moisture, and titratable acidity and lower values of protein compared with that made using immobilized enzymes. Cheese made using free coagulant enzymes had, also, higher values of cheese ripening indices and total volatile fatty acids. On the other hand cheeses made with bovine and chicken enzymes had higher initial cheese ripening indices than the calf rennet cheeses, during the storage period. All cheeses showed gradual loss of yield, moisture, and $\mathrm{pH}$ values during storage while, protein, fat and titratable acidity were increased in both immobilized or free enzymes cheeses. Gradual increase in cheese ripening indices and total volatile free fatty acids (TVFFAs) contents were noticed in all treatments, during 90 days of ripening. Retained enzymes were found lower in cheese curds made using immobilized enzymes and higher in whey of cheese made using free ones. Organoleptic evaluation revealed that cheeses of calf rennet, either free or immobilized, were slightly prefered organoleptically, all over the storage period, than the other cheeses contained bovine or chicken pepsins. Calf rennet cheeses were characterized by clean flavor, firm and good body and texture. Bovine pepsin cheeses exhibit slightly bitter taste and to somewhat friable body and texture at the end of the storage period. Generally, no obvious differences were observed between free coagulant enzymes and immobilized ones, through the storage period and all the resultant cheeses were accetptable .This study demonstrated the beneficial effect of using the immobilization technique for cheese making to reduce the 
cost of production, by reusing the immobilized enzymes several times, compensation the shortage of animal coagulants (especially in calf rennet) and maintenance the quality of the resultant soft cheese.

\section{INTRODUCTION}

Using calf rennet for milk coagulation is the most procedure used in cheese making. However, the worldwide increase in cheese production coupled with the reduced supply and increasing prices of calf rennet, has led to search for alternative milk clotting enzymes as an appropriate rennet substitute (Anusha et al., 2014). A part from this some religious factors (Islam and Judaism) and others related to veganism of some consumers have limited their use (Shah et al., 2014). Rennet calve was and still the most widely used in cheese manufacturing. It is milk-clotting enzyme preparation, which is extracted from the calf's fourth stomach of claves before its weaning (Guiama et al., 2010). Milk clotting properties of the rennet are derived from chymosin as the main enzyme component (EC 3. 4.234) that often called rennet, which is considered the best coagulant factor due to high specificity in breaking the bond between Phenyl alanine 105 and Methionine 106 in kappa-casein (Ahmed et al, 2009).

Cheese is traditionally made by batch system and current practice is by using clotting soluble enzymes. The normal methods have three negative aspects :1- The high cost of calf rennet 2- Using large quantities of enzymes, which remain in the clotting cheese 3- The appearance of bitter taste when the enzyme has highly proteolytic activity. The global increase in cheese production and its consumption with low providing of rennet and consequent increase in its prices have led to the attempt to fix the former negative aspects of the coagulant enzymes as well as reusing them several times when manufacturing cheeses (Gary and Johri, 1993).

Using of calf rennet as a milk clotting enzyme in the manufacture of cheese has been predominant in the industry for centuries. Lately, a worldwide shortage of this enzyme has been predicted due to the increase in production and consumption of cheeses besides the simultaneous decrease in the general availability of suckling calves' stomachs. Consequently, a great deal of interest has been generated in research for other effective and competitive substitutes for calf rennet . However, only a few other animal proteases - such as pig, chicken and bovine pepsins -and some microbial rennet preparations have been found suitable as a rennin substitute and are presently used in cheese making (Green, 1977 ) .

Enzymes immobilization or stabilization is one of the most important geometric strategies and defined as any capable technique of allowing reuse or continuous use of biocatalyst. Based on the nature of the reaction that will lead to the validation, the methods can be classified as physical and chemical, for being inverse and irreversible and according to another widely used classification system, three types of immobilization can be 
distinguished: 1- linkage to the vector 2- retention (capsulation) 3- cross linkage (Esposito, 2015). One of the most important properties of immobilized enzyme is the simplicity, effectiveness and the cost that effect on the used method, since the insoluble immobilized enzymes will allow the continuity in the enzymatic processes, control the output configuration, easily of separated enzyme, stop rapidly of resulting product and reuse it and improve the stability of the enzyme (Cao et al, 2003). Recently, the immobilization of milk clotting enzymes has indicated a renewed interest in several potential new applications for the removal of the immobilized enzymes after the thrombosis has been completed. In addition, enzyme proteolytic effectiveness can also be controlled during the whole process, when ripening of the cheese, give it stability and protection of the enzymes from the external influences (Gary and Johri, 1993). Using the associated enzymes in the cheese industry was not commercially viable, and until 1969 the immobilized enzymes were not used. Several studies have observed that most immobilizing methods can be used in bind ripening enzymes to milk. Taylor and Richardson (1978) was able to manufacture cheese continuously by binding the coagulant product of DOI of(the genus Mucor) with glass balls. It was found about $70-90 \%$ of the stabilized enzyme's activity doesn't alter through cheese industry because of the ability of enzymes to protect themselves (Holmes et al, 1977). The main of that research is to install the rennet (from the fungal organism Mucor miehei), which is widely used in the manufacture of cheeses, on paraffin wax and honey wax to compare it with the properties of free rennet, in order to determine the optimal conditions. The paraffin wax has been used as a supporting material due to its economical and technically safe on the industrial and laboratory scale, improving the stability of the rennet and reuse it after being immobilized after coagulation.

Several applications were utilized this technique of enzymes immobilization in the field of dairy products such as : immobilizing different alkaline proteases on anion exchange resin with glutar ( Ohmiya etal., 1978), immobilizing chymosin on paraffin wax (Shindo etal.,1984), immobilizarion of pepsin on paraffin wax ( Savangikar and Joshi,1978), immobilizarion of calf rennet and Mucor miehei rennet in manufacturing Ras cheese (Saad,1986 ), immobilizarion of free and microbial rennet in Domiati cheese (Mansour etal, 2011) .

Therefore, the main objective of the present study was to extract, purify and use of milk clotting enzymes of bovine, chicken pepsin and calf rennet either in free form or immobilized on mixture of paraffin \& honey waxes $(1: 1, \mathrm{w} / \mathrm{w})$, to study its effect on chemical, ripening indicies and sensory properties of the resultant white soft cheese, during 90 days of storage period. 
Materials:

\section{MATERIALS AND METHODS}

\section{Milk supply}

Fresh cow's milk was obtained from the herd belonged to Sidis Experimental Station, Animal Production Research Institute, Agriculture Research Center, Egypt .

Ammonium sulphate, sodium acetate, and other chemicals were purchased from Gomhoria company, Beni Suef Governorate, Egypt.

Salt , paraffin and honey waxes and ordinary white cotton cloth : tailored to strips $(5 \times 1.5 \mathrm{~cm})$ and sheets $24.5 \times 17 \mathrm{~cm}$ were used for enzymes immobilization from the local market .

Preparation of crude coagulant enzyme extracts :

1. Rennet calf extract : was prepared according to the method of Ahmed et al. (2013), with some modification.

2. Bovine Pepsin extract: The big bovine stomach tissues were obtained from butcher in Beni Sweef, The abomasum's were obtained from cow of 3 years age . It was prepared by the methods of Fahmi and Amer (1962) and Fahmi et al., (1979).

3. Chicken pepsin extract: was prepared according to the method mentioned by Ali and Salim,(1983).

All enzyme extracts were kept in the refrigerator at $5 \pm 1{ }^{\circ} \mathrm{C}$ until used.

Immobilization of bovine pepsin, chicken pepsin and calf rennet enzymes:

Immobolization was done according to Savangikar and Joshi, (1978) methods .

White soft cheese making using free and Immobilized enzymes.:

White soft cheese was made according to the method adopted by Metwalli et al. (1982). Cow's milk (3.60 fat), was salted at a level of $8 \%$, heat treated at $73^{\circ} \mathrm{C}$ for $5 \mathrm{sec}$., cooled to about $42^{\circ} \mathrm{C}$ and divided into six equal parts as follows:

First part (F1): contained free calf rennet (control)

Second part (F2): contained free bovine pepsin

Third part (F3): contained free chicken pepsin .

The other 3 parts were carried out as follows:

Fourth part (Z1): contained immobilized calf rennet.

Fifth part (Z2): contained immobilized bovine pepsin.

Six part (Z3): contained immobilized chicken pepsin.

Milk of all treatments were incubated at $40^{\circ} \mathrm{C}$, draining the whey, cutting the curds into cubes and pickled in $10 \%$ salt solution using the own drained whey of each treatment. Cheese samples were taken when fresh and after 30, 60 and 90 days of storage for analysis. 


\section{Analytical methods:}

- Titratable acidity, moisture, total solids, fat and total protein contents of milk and cheese were determined according to the methods described by Ling (1963).

- $\mathbf{p H}$ values of milk and cheese were measured using a combined calomel glass electrode $\mathrm{pH}$-meter model HANNA instruments H 18424.

- Cheeses Yield: was calculated as a weight of cheese divided by the weight of milk and expressed as a percentage value (Nelson et al., 2004).

- Proteolysis: was carried out by the determination of: (1) Water soluble nitrogen; Non protein nitrogen contents in cheese , according to Kuchroo and Fox (1982). Phosphotungstic acid (5\%) soluble nitrogen was determined according to Jarrett, et al. (1982).

- Tota volatile fatty acids in cheese was determined according to (Kosikowski,1987). and expressed as ml 0.1 N NaoH/100 g cheese.

- Residual rennet determination: was determined according to Dulley (1974) .

- Organoleptic properties:

Cheese samples were evaluated according to the method of Pappas et al. (1996) when fresh and after 30, 60 and 90 days of storage at room temperature. An overall score points out of (100 points) was given for flavour (50 points), body \& texture (35 points), appearance (10points) and colour ( 5 points) by a panel test consisted of twelve. persons, mainly from staff members.

\section{Chemical composition of raw cows milk}

\section{RESULTS AND DISCUSSION}

The chemical composition and $\mathrm{pH}$ value of raw cows milk was illustrated in Table (1).

Table 1. Chemical composition of cows milk used in white soft cheese making.

\begin{tabular}{|c|c|}
\hline Ingredients & Parameters \\
\hline Protein & $3.45 \%$ \\
\hline Fat & $\mathbf{3 . 6 0 \%}$ \\
\hline Total solids & $\mathbf{1 2 . 3 0 \%}$ \\
\hline Non-fat solids & $\mathbf{8 . 7 5 \%}$ \\
\hline Acidity & $\mathbf{0 . 1 6 \%}$ \\
\hline PH value & $\mathbf{6 . 6}$ \\
\hline
\end{tabular}

\section{Cheese Yield}

-Casein fraction of milk protein is the dominant factor affecting curd firmness, syneresis rate, moisture retention, and ultimately affecting cheese quality and yield (Lawrence, 1993).

- Data in Table (2) revealed, generally, that the yield of free and immobilized calf rennet cheeses were found the highest during storage 
period than the other treatments. Saad, (1986) found that the yield of Ras cheeses manufactured by immobilized enzymes was slightly lower than that of free enzymes .The yield of fresh cheese made using free calf rennet (control) was \%23.2 decreased to $19.6 \%$ after 90 days of storage, while those made using immobilized calf rennet was 21.8.\%, decreased to $19.1 \%$.

- Chicken pepsin cheeses recorded yield values slightly more than bovine pepsin cheeses .

- Yield of all free enzymes of fresh cheeses were ranged between 21.4 to $23.2 \%$ decreased to 18.3 to 19.6 after 90 days of ripening. The corresponding values of immobilized enzymes in fresh cheeses were 19.1 to $21.8 \%$ decreased to 17.4 . The main reason for decreasing the yield in pepsin cheese treatments either contain free or immobolized enzymes was the weak coagulation activity of these enzymes as well as its high rate of proteolysis, during storage, which reflect on the total solids contents and subsequently on the yield.

- These observations were supported by (Bruno et al., 2010) who said that the speed of hydrolysis of caseins influences in yield, and slow degradation of $\alpha$ s-and $\beta$-caseins is guarantee production of a firm curd, which is occurs when chymosin is used. Most rennet substitutes are more proteolytic than calf rennet and cause diminished yields .

\section{Physico-chemical composition}

Result present in Table (2) illustrate the Physico-chemical composition of white soft cheese during storage .

- Moisture was found the lowest in calf rennet cheeses (F1and Z1) than in the other treatments (F2, Z2 , F3 and Z3) . Moisture contents in free enzymes of fresh cheeses ranged between $63.40-66.70 \%$ decreased to $60.90-61.90 \%$ after 90 days of storage period while the similar ones of the immobilized enzymes were $62.90-64.60 \%$ in fresh cheeses decreased to $60.50-61.0 \%$.

- protein contents were higher in calf rennet cheeses than the other treatments.It increased gradually during storage and decreased in all treatments, at the end of the storage period owing to the action of proteolytic microorganisms, and the higher rate of increase in the cheese ripening indices ( soluble and non-protein nitrogen) . protein contents were 14.40 -15.50 in fresh cheeses contained free enzymes decreased to $14.70-15.50 \%$, at the end of the storage period whereas those of immobilized cheeses were $14.70-15.80 \%$ in fresh cheeses deceased latterly to $15.40-15.60 \%$.

- Fat contents of all treatments ( free or immobilized ) were found approximately near during storage period with the irrespective of chicken 
pepsin treatments which were slightly higher . It ranged between 19.20 $20.30 \%$ in free enzymes cheeses and $18.80-20.20 \%$ in fresh immobilized ones . Fat contents were decreased in all treatments during storage as a result of the action of the lipolytic bacteria .

- Titratable acidity (TA) was found low in free or immobilized calf rennet fresh cheeses ( F1 and Z1 treatments) than the rest treatments, along the storage period, because most of rennet substitutes ( bovine and chicken pepsins ) are more proteolytic than calf rennet and resulting in higher amounts of organic acids and other minor proteins used by the lactic acid bacteria .

- TA in fresh cheeses contained free enzymes (F1, F2 and F3) ranged between $0.18-0.20 \%$ increased to $1.22-1.32 \%$ after 90 days of storage , while the immobilized ones were $0.16-0.19 \%$ in fresh cheeses increased to $1.16-1.21 \%$.

- pH values of all treatments behaved reverse trend to TA all over the storage period.

Table 2: Physico-chemical analysis of white soft cheese made by using free or immobilized coagulant enzymes, during storage period.

\begin{tabular}{|c|c|c|c|c|c|c|c|}
\hline \multirow[b]{2}{*}{ Treatments } & \multirow{2}{*}{$\begin{array}{c}\text { storage } \\
\text { period } \\
\text { (days) }\end{array}$} & \multicolumn{6}{|c|}{ parameters $(\%)$} \\
\hline & & $\begin{array}{c}\text { Yield } \\
\%\end{array}$ & Moisture & Protein & Fat & pH & Acidity \% \\
\hline \multirow{4}{*}{$\begin{array}{c}\text { F1 } \\
\text { (control) }\end{array}$} & Fresh & 23.2 & 63.4 & 15.6 & 19.3 & 6.45 & 0.18 \\
\hline & 30 & 21.8 & 62.2 & 15.8 & 20.5 & 6.28 & 0.26 \\
\hline & 60 & 20.4 & 61.8 & 16.0 & 21.2 & 5.78 & 0.93 \\
\hline & 90 & 19.6 & 60.9 & 15.5 & 21.6 & 5.21 & 1.22 \\
\hline \multirow{4}{*}{$\mathbf{Z 1}$} & Fresh & 21.8 & 62.9 & 15.8 & 19.0 & 6.55 & 0.16 \\
\hline & 30 & 20.5 & 61.8 & 16.1 & 20.2 & 6.37 & 0.25 \\
\hline & 60 & 19.2 & 61.4 & 16.7 & 20.4 & 5.83 & 0.87 \\
\hline & 90 & 19.1 & 60.5 & 15.4 & 21.2 & 5.38 & 1.16 \\
\hline \multirow{4}{*}{ F2 } & Fresh & 21.4 & 66.7 & 15.2 & 19.2 & 6.36 & 0.19 \\
\hline & 30 & 18.7 & 64.5 & 15.6 & 20.2 & 6.19 & 0.27 \\
\hline & 60 & 17.3 & 62.0 & 15.8 & 20.9 & 5.38 & 0.96 \\
\hline & 90 & 16.6 & 61.4 & 15.6 & 21.3 & 5.24 & 1.29 \\
\hline \multirow{4}{*}{$\mathbf{Z 2}$} & Fresh & 19.1 & 65.2 & 14.8 & 18.8 & 6.44 & 0.18 \\
\hline & 30 & 18.4 & 63.1 & 15.2 & 20.0 & $\begin{array}{l}6.27 \\
\end{array}$ & 0.26 \\
\hline & 60 & 16.8 & 61.6 & 15.9 & 20.2 & 5.56 & 0.89 \\
\hline & 90 & 16.1 & 61.2 & 15.6 & 21.0 & 5.29 & 1.18 \\
\hline \multirow{4}{*}{ F3 } & Fresh & 21.9 & 65.2 & 14.4 & 19.2 & 6.41 & 0.20 \\
\hline & 30 & 20.4 & $\begin{array}{l}63.0 \\
\end{array}$ & 14.7 & 20.3 & 6.19 & 0.28 \\
\hline & 60 & 19.1 & 62.8 & 15.5 & 21.0 & 5.49 & 0.99 \\
\hline & 90 & 18.3 & 61.9 & 15.4 & 21.4 & 5.32 & 1.32 \\
\hline \multirow{4}{*}{$\mathbf{Z 3}$} & Fresh & 20.4 & 64.6 & 14.7 & 18.9 & 6.53 & 0.19 \\
\hline & 30 & 19.3 & 62.3 & 15.0 & 20.1 & 6.13 & 0.27 \\
\hline & 60 & 18.2 & 61.8 & 16.1 & 20.4 & 5.35 & 0.91 \\
\hline & 90 & 17.4 & 61.0 & 15.4 & 21.2 & 5.35 & 1.21 \\
\hline
\end{tabular}

F1 : Free calf rennet,control

F2 : Free bovine pepsin

F3 : Free chicken pepsin
Z1 : Immobilized calf Rennet .

Z2 : Immobilized bovine pepsin .

Z3 : Immobilized chicken pepsin . 


\section{Proteolysis :-}

The proteolytic activity in cheese can be estimated by the release of a small nitrogen-containing fractions (soluble nitrogen/total nitrogen (SN/TN), phospho tungstic acid - soluble nitrogen/total nitrogen (PTA $\mathrm{SN} / \mathrm{TN}$ ) and non-protein nitrogen /total nitrogen (NPN/ TN )) from the protein (Visser, 1977).

- Results in (Table 3) showed an increase in the percentage of these ripening indices ( SN/TN, PTA - SN/TN and NPN/ TN ) in the free enzymes of calf rennet ( treatment, F1 ), bovine and chicken pepsin( treatments F2 and F3 ), compared to the immobilized ones ( $\mathrm{Z} 1$,Z2 and $\mathrm{Z3}$ ), during the storage period .

- The initial values of these fractions in free calf rennet cheeses were lower than that of free chicken pepsin and bovine pepsin cheeses, respectively. Values of SN / TN were $6.54,7.34$ and $8.12 \%$ in free enzymes cheeses, while the same values were $5.34,6.91$ and $7.23 \%$ in the immobilized ones .

- At the end of the storage period these values were increased to 23.68 , 24.62 and $25.48 \%$ respectively and to $22.41,23.88$ and $23.96 \%$, in the immobilized ones.The main reason for increasing these values in bovine and chicken cheeses was the higher rate of proteolysis took placed by pepsin enzymes than the calf rennet enzymes.

- Results revealed, moreover, that the trend in the changes in NPN/TN and PTA-SN/TN in cheeses was found the same as in the SN / TN.

- Slight differences between values of free and immobilized enzymes were observed and bovine pepsin recorded higher values than chicken pepsin, along the storage period .

- Several studies were done to compare calf rennet with pepsin enzymes in the field of cheese production e.g Gordin and Rosenthal (1978) who used calf rennet and chicken pepsin in the manufacture of Emmental-and Kashkaval cheeses .

\section{Lipolysis:}

- Data in Table (3) show, also, that the amount of TVFFA were increased gradually in all cheeses either contained free or immobilized enzymes, throughout the storage period.

- Cheeses contained free enzymes calf rennet, bovine and chicken pepsin had higher values of TVFFA compared with the immobilized ones, during storage .

- The TVFFA contents in free enzymes fresh cheeses were $6.8,7.1$ and 7.4 while it were 5.4, 6.4 and 6.6 in immobilized ones, respectively. 
These values increased to $18.3,19.6$ and 20.1 and 15.7, 16.2 and 16.8 , at the end of the storage period, respectively.

- Also, data cleared that the TVFFA were slightly higher in cheese made with bovine pepsin than the other treatments.

Table 3: Changes in total, soluble nitrogen and total volatile fatty acids (TVFFA) contents of white soft cheese made with free or immobilized coagulants, during storage period.

\begin{tabular}{|c|c|c|c|c|c|}
\hline \multirow{2}{*}{ Treatments } & \multirow{2}{*}{$\begin{array}{c}\text { Ripening } \\
\text { period } \\
\text { (days) }\end{array}$} & \multicolumn{4}{|c|}{ Parameters (\%) } \\
\hline & & $\mathbf{S N} / \mathbf{T N}$ & NPN/TN & PTA-SN/TN & TVFFA \\
\hline \multirow{4}{*}{$\begin{array}{c}\text { F1 } \\
\text { (control) }\end{array}$} & Fresh & 6.54 & 5.22 & 4.23 & 6.8 \\
\hline & 30 & 18.73 & 7.48 & 5.77 & 9.4 \\
\hline & 60 & 19.84 & 10.62 & 8.88 & 16.2 \\
\hline & 90 & 23.68 & 13.55 & 11.32 & 18.3 \\
\hline \multirow{4}{*}{$\mathbf{Z 1}$} & Fresh & 5.34 & 4.36 & 4.01 & 5.4 \\
\hline & 30 & 17.28 & 6.92 & 5.32 & 8.2 \\
\hline & 60 & 18.77 & 9.64 & 7.96 & 14.3 \\
\hline & 90 & 22.41 & 12.11 & 10.42 & 15.7 \\
\hline \multirow{4}{*}{ F2 } & Fresh & 8.12 & 6.72 & 4.76 & 7.4 \\
\hline & 30 & 20.44 & 8.33 & 6.13 & 10.3 \\
\hline & 60 & 21.86 & 11.13 & 9.27 & 18.6 \\
\hline & 90 & 25.48 & 14.04 & 12.53 & 20.1 \\
\hline \multirow{4}{*}{$\mathbf{Z 2}$} & Fresh & 7.23 & 5.37 & 4.41 & 6.6 \\
\hline & 30 & 19.04 & 7.24 & 5.73 & 9.1 \\
\hline & 60 & 20.38 & 9.83 & 8.52 & 15.5 \\
\hline & 90 & 23.96 & 12.98 & 11.72 & 16.8 \\
\hline \multirow{4}{*}{ F3 } & Fresh & 7.34 & 6.40 & 4.43 & 7.1 \\
\hline & 30 & 19.88 & 7.74 & 5.96 & 9.8 \\
\hline & 60 & 20.59 & 10.65 & 8.99 & 16.4 \\
\hline & 90 & 24.62 & 13.27 & 12.04 & 19.6 \\
\hline \multirow{4}{*}{ Z3 } & Fresh & 6.91 & 5.12 & 4.28 & 6.5 \\
\hline & 30 & 18.68 & 6.82 & 5.74 & 8.7 \\
\hline & 60 & 19.87 & 9.54 & 8.28 & 14.9 \\
\hline & 90 & 23.88 & 12.38 & 11.47 & 16.2 \\
\hline
\end{tabular}

See abbreviations under Table (2) .

Retention of free or immobilized coagulant enzymes in cheese curds and whey :

- Coagulant enzymes plays important role in the ripening process of the cheese by promoting hydrolysis of casein into large peptides. The concentration of the coagulant enzymes in cheese depends on some technological factors such as pre-treatment of milk, cooking temperature, variety of cheese, type of coagulant, $\mathrm{pH}$ value of the curd at cutting, $\mathrm{pH}$ at whey drainage, and moisture level of the final cheese (Hurley et al., 1999).

- Various techniques have been used to eliminate the activity of residual coagulants in cheese in order to study its role in cheese ripening (Fox and McSweeney, 1996). 
- Results in Table (4) showed the residual coagulant enzymes retention in the curd and whey of the resultant cheeses contained free or immobilized coagulant enzymes and expressed as coagulation time (CT) per seconds. Results indicated that the rate of retention of enzymes in the curd (CT) was proportional with the amount of free or immobilized coagulant enzymes remained in the curd or whey.

- Coagulation time were found higher in cheese curds made using immobilized enzymes compared with those made using free ones . Also it was lower in cheese curd made using free or immobilized bovine pepsin than both chicken pepsin or calf rennet.

- The average values of CT for free calf rennet, bovine and chicken pepsin cheeses were: 563, 490, and $523 \mathrm{sec}$, respectively. While the average values of CT for immobilized ones were 832, 734 and 787 sec., respectively.

- The CT was higher in calf rennet whey than the other two treatments cheeses. The average values of CT in the whey of free calf rennet, bovine and chicken pepsin were: 287, 235 and $251 \mathrm{sec}$., while in immobilized ones were 458, 384 and 373 sec. respectively.

Table (4): Effect of free or immobilized coagulant enzymes on the residual coagulants remained in curd and whey, after drainage stage.

\begin{tabular}{|c|c|c|c|}
\hline \multirow{2}{*}{ Treatments } & \multirow{2}{*}{ Enzyme state } & \multicolumn{2}{|c|}{ Coagulation time (sec.) } \\
\cline { 3 - 4 } & Free $\left(\mathbf{F}_{1}\right)$ & Whey & curd \\
\hline \multirow{2}{*}{ Calf rennet } & Immobilized $\left(\mathbf{Z}_{1}\right)$ & $\mathbf{2 8 7}$ & $\mathbf{5 6 3}$ \\
\hline \multirow{2}{*}{ Bovine pepsin } & Free $\left(\mathbf{F}_{2}\right)$ & $\mathbf{4 5 8}$ & $\mathbf{8 3 2}$ \\
\cline { 2 - 4 } & Immobilized $\left(\mathbf{Z}_{2}\right)$ & $\mathbf{2 3 5}$ & $\mathbf{4 9 0}$ \\
\hline \multirow{2}{*}{ Chicken pepsin } & Free $\left(\mathbf{F}_{3}\right)$ & $\mathbf{3 7 3}$ & $\mathbf{7 3 4}$ \\
\cline { 2 - 4 } & Immobilized $\left(\mathbf{Z}_{3}\right)$ & $\mathbf{2 5 1}$ & $\mathbf{5 2 3}$ \\
\hline
\end{tabular}

See abbreviations under Table (2) .

Sensory evaluation of cheese

- Sensory evaluation of white soft cheese is a valuable criterion for determining cheese quality and acceptability. The body, texture and flavour are affected considerably by many factors such as type of milk, pre-treatment of milk, season of milk production, addition of starter to milk, type of coagulant used, percentage of salt in both the cheese curd and the pickling solution, microflora of the cheese milk, additives to the cheese milk to accelerate the cheese ripening and storage temperature during ripening (Pappas et al., 1996). Chymosin is the major enzyme of calf rennet, and it has been widely used in the 
dairy industry to produce a stable curd with good flavour due to its high specificity for the Phenyl alanine105-Methionine106 bond of kcasein (Rao et al., 1998).

- Sensory evaluation revealed that cheeses of calf rennet, either free or immobilized, were slightly prefered organoleptically, all over the storage period, than the other cheeses contained bovine or chicken pepsin .Calf rennet cheeses were characterized by clean flavor, firm and good body and texture. Mansour et al. (2011) observed that Domiati cheese made with free microbial rennet gained higher scores than that using immobilized microbial rennet.

- Bovine pepsin cheeses exhibit slightly bitter taste and to somewhat friable body and texture at the end of the storage period, owing, presumably, to the higher rate of proteolysis occurred by the pepsin enzymes .

- Chicken pepsin cheeses were found slightly better than bovine pepsin cheeses, during 90 days of storage.

- No obvious differences were observed between free coagulant enzymes and immobilized ones, through the storage period. These observations were in line with Shindo et al. (1984), who found no great differences were observed between the quality of cheese produced with immobilized enzyme and the cheese produced by the free enzyme.

- Generally, all the resultant cheeses were acceptable with the exception of bovine pepsin cheeses which were slightly inferior . It is known that sensory properties of flavour, colour and texture are key factors for final product acceptance (Abdul-Rahman, 2013).

\section{CONCLUSION}

Results of this experiment showed that the calf rennet, bovine and chicken pepsins were successfully immobilized on paraffin / hony waxes (1:1 mixture) cloth strips. Yield and chemical composition of cheese manufactured by immobilized enzymes was slightly lower than that of free enzymes. Generally, small differences among all treatments, contained either free or immobilized coagulants, were found. The amount of clotting enzymes retained in free enzyme cheeses were relatively twice as much as that of immobilized enzyme cheeses. Sensory evaluation revealed, moreover, that immobilized enzymes cheeses were relatively lower organoleptically than those of free enzyme cheeses. This study demonstrated the beneficial effect of using this technique of immobilization for cheese making to reduce the high cost of cheese 
production by reusing the immobilized enzymes sevral times in clotting numerous batches of milk. In addition this technique will compensate the shortage of animal rennet in the local market.

\section{REFERENCES}

Abdul-Rahman, S.M. (2013). Using of safflower (Cartamus tinctorius) seeds extract for white soft cheese manufacturing. J. Tikrit Univ. Agri. Sci., 13: 39-44.

Ahmed, I.A.M. ; I. Morishima ; E.E. Babiker and N. Mori (2009). Characterisation of partially purified milk-clotting enzyme from Solanum dubium Fresen seeds. Food Chem., 116: 395-400.

Ahmed, G. ; S.A. Khan ; M. Khaskheli ; M.A. Qureshi and I. Ahmad (2013). Production and properties of rennet from buffalo calves abomasam. J. Anim. and Plant Sci., 23: 5-9.

Ali, L.A. and R.M. Salim (1983). Cheese And Fermented Milk Manufacturing. University of El- Mosl, El-Mosl, Iraq .

Anusha, R. ; M.K. Singh and O. Bindhu (2014). Characterization of potential milk coagulants from Calotropis gigantea plant parts and their hydrolytic pattern of bovine casein. European Food Res. and Technol., 238: 997-1006.

Bruno, M.A. ; C.M. Lazza ; M.E.L. Errasti ; L.M.I. López ; N.O. Caffini and M.F. Pardo (2010). Milk clotting and proteolytic activity of an enzyme preparation from Bromelia hieronymi fruits. LWT-Food Sci. and Technol., 43: 695-701.

Cao, L. ; L.V. Langen and R.A. Sheldon(2003): Immobilized enzymes: carrier-bound or carrier free? Curr. Opin. Biotechnol., 14: 387394.

Dulley, J.R. (1974). The contribution of rennet and starter enzymes to proteolysis in cheese. Aust. J. Dairy Tech. June, p: 65.

Esposito, M. (2015). Extraction and immobilization of vegetable Aspartic proteases for cheese making. Ph.D. Thesis, University of Naples, Italy

Fahmi, A.H. and S.N. Amer (1962). A study on the preparation of liquid rennet extract. (ln Arabic). Megallet El-Eloum El-Zeraiea, Cairo Univ.,15: 10.

Fahmi, A.H.; S.N. Amer and M.A. El-Batawy (1979). Adult bovine vells as a source of rennet. Egyptian J. Dairy Sci., 7 : 33.

Fox, P.F. and P.L.H. McSweeney (1996). Proteolysis in cheese. Food Reviews Int. 12: 457-509. 
Gary, S.K. and B.N. Johri (1993) . Immobilization of milk-clotting proteases. World J. Microb. Biot., 9: 139-144.

Green, M.L. (1977). Review of the progress of dairy science: Milk coagulants. J. Dairy Res., 44:159-188.

Gordin, S. and I. Rosenthal (1978). Efficacy of Chicken Pepsin as a Milk Clotting Enzyme. Journal o\{Food Protection., 41(9):684688 .

Guiama, V.D. ; D.G. Libouga ; E. Ngah ; R.G. Beka ; A.C. Ndi ; B. Maloga ; J.M. Bindzi ; P. Donn and C.M. Mbofung (2010) . Milk clotting potential of fruit extracts from Solanum esculentum, Solanum macrocarpon L. and Solanum melongena. Afr. J. Biol., 9(12): 1797-1802.

Holmes, D.G. ; J.W. Daerch and C.A. Ernston (1980). Distribution of milk clotting enzymes between crud and whey and their survival during Chedder cheese making. J. Dairy Sci., 60: 862-869.

Hurley, M.J. ; B.M.O'Driscoll ; A.L.Kelly and P.L.H. McSweeney (1999). Noval assay for the determination of residual coagulant activity in cheese. Int. Dairy J., 9: 553-558.

Jarrette, W.D.; J.W. Aston and J.R. Dulley (1982). A simple method for estimating free amino acids in Cheddar cheese. Aust. J. of Dairy Tech., 37: 55-58.

Kosikowski, F.V. (1987): Cheese and fermented milk foods. 9nd Printing with revistions (1987).573.F.V.Kosikowski and Associates, P.O.139 Brooktondale, Ithaca. N. Y.USA.

Kuchroo, C.N. and P.F. Fox (1982): Soluble Nitrogen in Cheddar cheese: comparison of extraction procedures. Milchwissenschaft, 37 (6): 331-335.

Lawrence, R.C. (1993). Relationship between milk protein genotypes and cheese yield capacity. In: Factors Affecting the Yield of Cheese. In: Emmons D. B. (Ed.). Int. Dairy Federation, Brussels, 121-127.

Ling, E.R. (1963): A text Book of Dairy Chemistry. Vol. 2, practical, 3rd edition publishers Chapman and Hall limited, London.

Mansour, A.I.; F.S. Ibrahim ; A.S. Zahran and M.H. Nagm ElDiin (2011). Assessment of domiati cheese made using free and immobilized microbial rennets. Minia J. of Agric. Res. \& Develop.,31(1):135-150.

Metwalli, N.H. ; S.I. Shalabi ; A.S. Zahran and O. El-Demerdash (1982): The use of Soybean milk in soft cheese making: Organoleptic and chemical properties of Domiati cheese made from a mixture of Soybean milk and whole milk. Journal of Food Technology, 17: 297-305. 
Nelson, B.K. ; J.M. Lynch and J.M. Barbano (2004). Impact of milk preacidfication with $\mathrm{CO}_{2}$ on Cheddar cheese composition and yield. J. Dairy Sci., 87: 3581-3589.

Ohmiye, K. ; S. Tanimura ; T. Kobayashi and S. Shimizu (1978). Preparation and properties of proteases immobilized on anion exchange resin with glutar. Biotech. Bioeng., 21:1.

Pappas, C.P. ; E. Kondlyi ; L.P. Voutsinas and H. Mallatou (1996). Effects of starter level, draining time and aging on the physicochemical, organoleptic and rheological properties of feta cheese. Int. J. Dairy Technol., 49: 73-78.

Rao, M.B. ; A.M. Tanksale ; M.S. Ghatge and V.V. Deshpande (1998). Molecular and biotechnological aspects of microbial proteases. Microbiol. and Molecular Biol. Rev., 62: 597-635.

Saad, M.H. ( 1986). Studies on milk clotting enzymes. Ph.D. Thesis, Fac. of Agric., Alexandria Univ. Egypt.

Savangikar, V.A. and R. N. Joshi (1978). Immobilization of pepsin in active form in paraffin wax. J. Food Sci., 43:1616.

Shah, M.A. ; S.A. Mir and M.A. Paray (2014). Plant proteases as milkclotting enzymes in cheese making: A review. Dairy Sci. and Technol, 94:5-16.

Shindo, K. ; H. Sakamoto and S. Arima (1984). Studies on immobilized chymosin-the degradation of casein during cheese ripening. Hokkaido Daigaku Nagakubu Hdoun Kigo (Japan), 20: 83-87.

Taylar, M.J. and T. Richardson (1978). Application of microbial enzyme in food systems and biotechnology. Adv. J. Apple. Microbial, 25: 7-31.

Visser, F.M.W.(1977). Contribution of enzymes from rennet, starter bacteria and milk to proteolysis and flavour development in Gouda cheese. 9. Description of cheese and aseptic cheesemaking techniques. Netherland Milk Dairy Journal, 79: 991-977

Yun, J.J. ; L.J. Kiely ; P.S. Kındstedt, and D.M. Barbano (1993). Mozzarella Cheese: impact of coagulant type on functional properties, Journal of Dairy Science, 76: 3657-3663.

Zoon, P.; C. Ansems and E.J. Faber (1994). Measurement procedure for concentration of active rennet in cheese. Neth. Milk and Dairy J., 48: 141-151. 
Egypt. J. of Appl. Sci., 36 (7-8) 2021

تقييم جودة وصفات الجبن الابيض الطري المصنع بواسطة الأنزيمات المجبنة الحرة والمثبتة أثناء التخزين

\author{
محمد علي أحمد

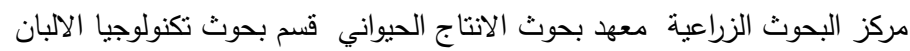

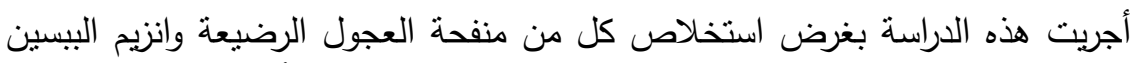

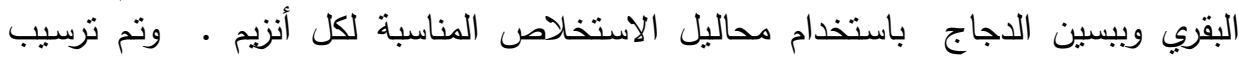

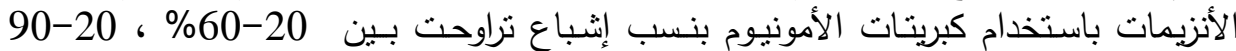

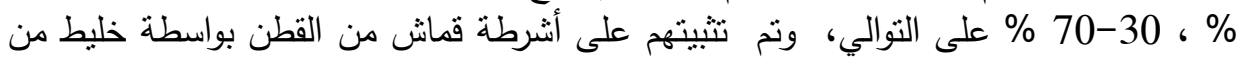

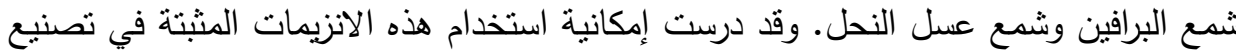

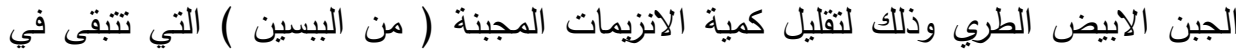
الجبن والتي قد تؤدي الى ظهور المذاق المر ، ومقارنتها بمثيلتها من الانزيمات الحرةعلى النحو التالي : التين والتي

1. تُ الاستخلاص والتتقية ثم التجهيز من تركيز وتجفيف للثناثة انواع من الأنزيمات المجبنة

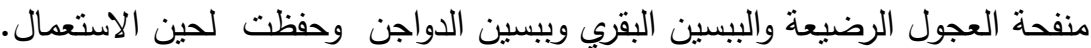

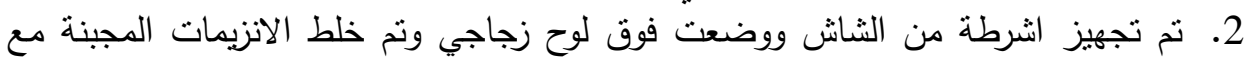

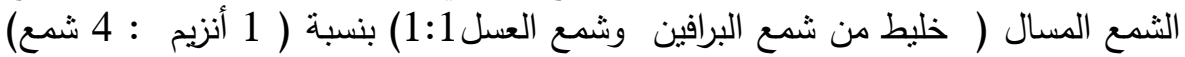

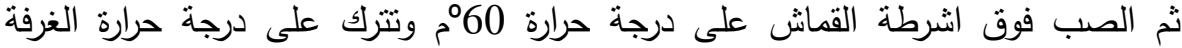

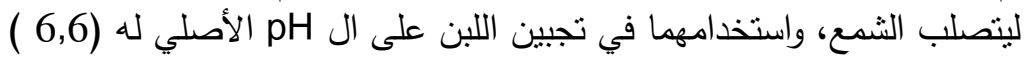

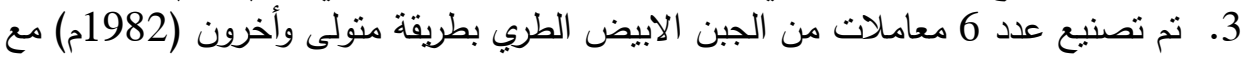

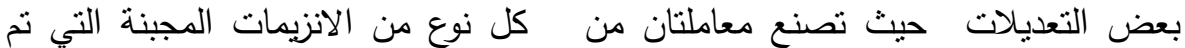

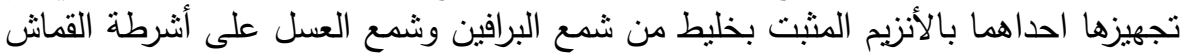

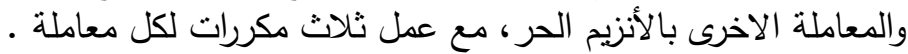

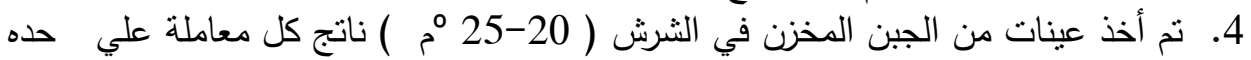

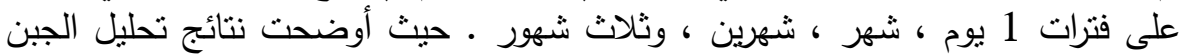

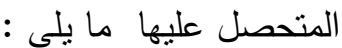

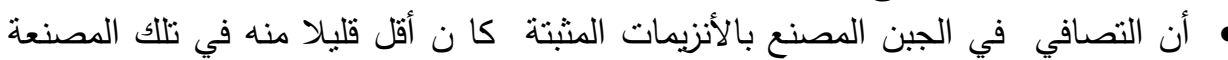

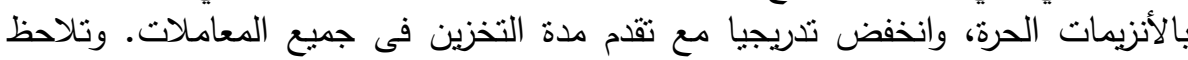

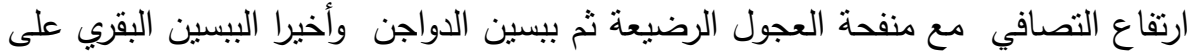
التوالي. كانت نسبة الرطوبة والحموضة اعلى نسبيا فى حين كانت نسبة البروتين منذفضة نسبيا

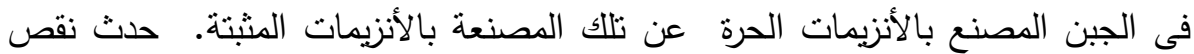

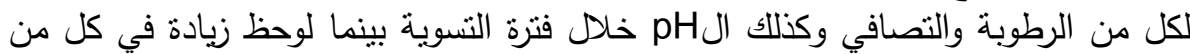

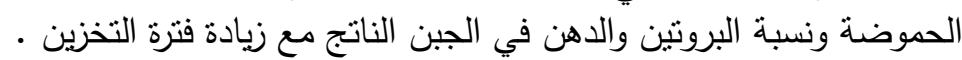




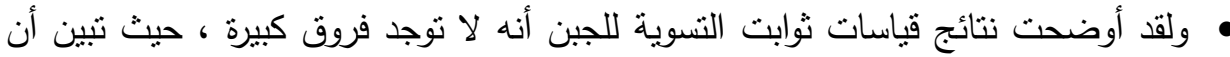

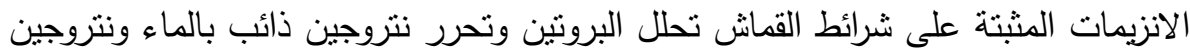

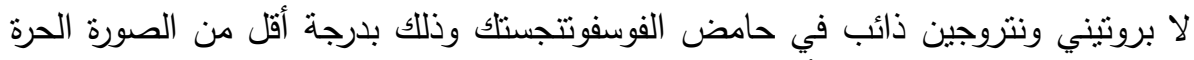

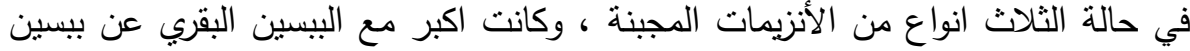

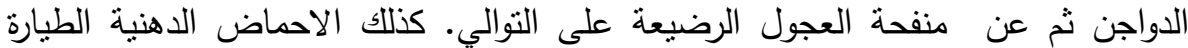

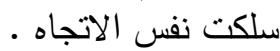

وجد ان نسبة الانزيمات المتقية في خثره وشرش جين الانزيمات الحره كانت اعلى من لناه

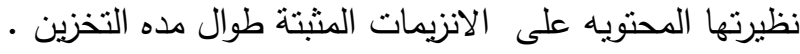

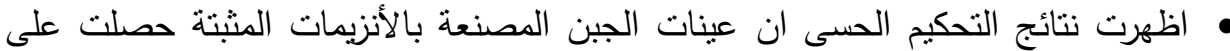

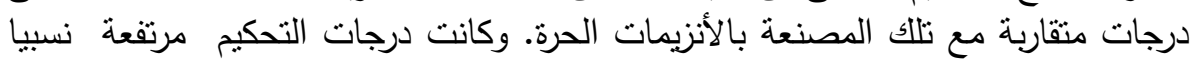

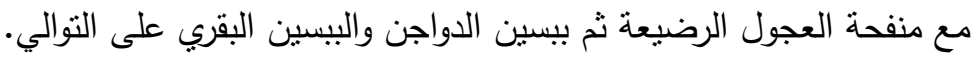

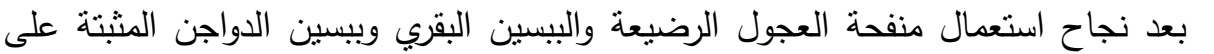

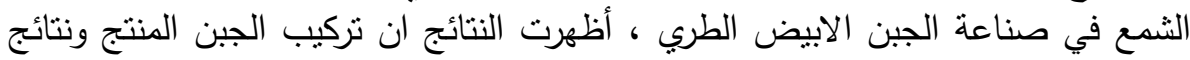

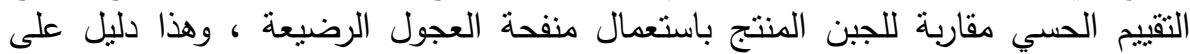

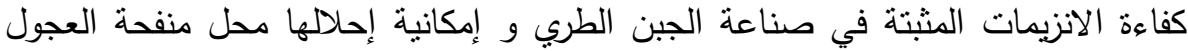

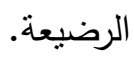
• اظهرت هذه الدراسه امكانيه استخدام هذه التقنيه الحديثه في تحميل الانزيمات المجبنه

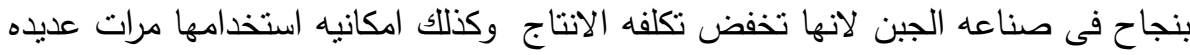

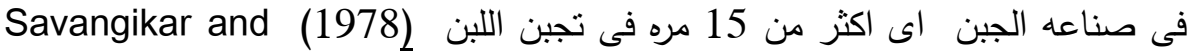
Shindo et al., (1984) and Joshi تعويضها النقص فى كميات المنفحه الحيوانيه فى السوق المحلى 